\title{
DOES EXPORT DIVERSIFICATION LEAD TO INCOME CONVERGENCE? EVIDENCE FROM CROSS-COUNTRY ANALYSIS
}

\author{
Vaseem Akram* and Badri Narayan Rath** \\ * Economics and Business Environment Area, Indian Institute of Management Jammu, Jammu and \\ Kashmir-180016, India. Email: akramvaseem001@gmail.com \\ ** Corresponding author. Department of Liberal Arts, IIT Hyderabad, Kandi, Sangareddy, Telangana \\ - 502285, India. Email: badri@la.iith.ac.in
}

\begin{abstract}
In this study, we examine the role of export diversification in the convergence of per capita income (output). By applying the dynamic system Generalized Method of Moments (GMM) estimator to a panel dataset consisting of 95 countries, we find evidence of both absolute and conditional divergence for the full sample and the subsamples based on income and regions. Thus, our findings suggest that, although high export diversification boosts the per capita income (output), it does not significantly reduce per capita income (output) gap between rich and poor countries.
\end{abstract}

Keywords: Export diversification; Economic growth; Conditional convergence.

JEL Classification: E60; F14; O30; C23.

\author{
Article history: \\ Received : September 10, 2019 \\ Revised : February 10, 2020 \\ Accepted : August 31, 2020 \\ Available online : October 31, 2020 \\ https://doi.org/10.21098/bemp.v23i3.1251
}




\section{INTRODUCTION}

The convergence hypothesis, which is based on neoclassical growth, has been traditionally developed for closed economies (see, for example, Baumol, 1986; Mankiw et al., 1992; Barro and Sala-i-Martin, 1995, 2003; Islam, 1995). An important question, which has been subsequently raised in the literature, is whether an increase in openness to international trade leads to per capita output (or income) convergence across economies (see, for example, Ben-David, 1993, 1996; BenDavid and Loewy, 1998; Rossini and Burattoni, 1996; Slaughter, 1997, 2001; Stehrer and Wörz, 2003; Felbermayr, 2005; Chatterjee and Shukayev, 2012; Song, 2014). Although seminal works by Ben-David (1996) and Slaughter (1997) highlight that there is a difference between factor price equalization and equalization of per capita income, there is limited theoretical literature examining the relationship between trade and income convergence. This aside, conclusions from existing theories are also ambiguous (see, for example, Ben-David, 1993, 1996).

Trade can either lead to income convergence or income divergence through many channels. One of these channels is factor prices (wage and rent), which are associated with factor price equalization theorem (see, for example, Samuelson, 1948; Helpman and Krugman, 1985). This theorem describes a condition whereby some limited restrictions are met such that free trade of goods lead to commodity price equalization and to subsequent equalization of factor prices. As a result, free trade does not only reduce the disparities in the prices of goods across countries but also equalizes the prices of nontradable factors. Further, Leamer and Levinsohn (1996) called it a Factor Price Convergence (FPC) theorem and according to them, "as barriers to international trade reduce, thereby prices converge since trade in goods becomes free". Thus, there is a tendency for declining variation in the factor prices across trading partners and, as a result, free trade may lead to convergence, of income across countries. However, FPC does not necessarily lead to a reduction in trade barriers which ensures income convergence. The FPC also depends on countries test, endowments, and technology. ${ }^{1}$ For instance, Deardorff (2001) argued that countries having diverse initial endowments may end up with unequal factor prices in different diversification cones. In this case, FPC will no longer hold. Further, Baldwin (1992) contended that trade reduces (raises) capital returns and discourages (encourages) investment in poor (rich) countries, which can lead to income divergence. Grossman and Helpman (1991) argued that trade could also drive income convergence through technology spillovers. However, they found that trade boots growth in poor countries and that there are cases where trade and competition may lead to income divergence by discouraging research in poor countries.

On the empirical front, the bulk of studies provide sufficient evidence the nexus between export diversification and economic growth (see, for example, Al-Marhubi, 2000; Balaguer and Cantavella-Jorda, 2004; Herzer and NowakLehmann, 2006; Lederman and Maloney, 2007; Agosin, 2007; Arip et al., 2010). The literature also explained that export diversification is an essential determinant of a total factor of productivity growth (for example see, Berthélemy and Chauvin,

\footnotetext{
1 A detailed theoretical explanation trade and income convergence can be found from Slaughter (1995, 1997), and Deardorff (1986).
} 
2000; Berthélemy and Soderling, 2001; Hammouda et al. 2010; Rath and Akram, 2017; Akram and Rath, 2017). Another group of studies (see, for instance, Murthy and Chien, 1997; McCoskey, 2002; Stroomer et al., 2003; Vollmecke et al., 2015; Li et al., 2016) examine the per capita output (or income) convergence hypothesis by emphasizing the role of international trade. However, studies on whether export diversification leads to output (or income) convergence are rare.

Thus, examining the role of export diversification in per capita income convergence/divergence is vital because export diversification is considered to be a better proxy for trade in morden trade theories (Al-Marhubi, 2000; Balaguer and Cantavella-Jorda, 2004; Herzer and Nowak-Lehmann, 2006; Lederman and Maloney, 2007; Agosin, 2007; Arip et al. 2010; Mau, 2015). Also, classical trade theories are based on multiple assumptions like perfect competition, comparative advantage, and constant return to scale, whereas the recent literature on trade found that countries appear to diversify in exports to achieve higher economic growth (Hammouda et al. 2010). In addition, it has been argued that poor countries can grow rich by modifying the compositions of their exports (or via export diversification), particularly by diversifying the economies away from primary commodities because of unfavourable and declining terms of trade, low valueaddition, and slow productivity growth - the so-called Prebisch Singer hypothesis. In addition, Mau (2015) claimed that it is not just exports which influence per capita income convergence, export diversification influences it as well. For instance, Romer (1990) argued that diversification is a production factor that may help boost a poor countries' economic growth, helping them 'catch up' with the rich countries. Acemoglu and Zilibotti (1997) argued that export diversification might uplift economic growth by expanding the possibilities of spreading investment risks over a wider portfolio. Export diversification is defined as the change in the structure of a country's existing export product basket or export destination (Ali et al., 1991) or spread of production over many sectors (Berthelemy and Chauvin, 2000). In other words, export diversification can be defined as broadening the product range that a country exports, thereby equated with export growth at the extensive margin (Dennis and Shepherd, 2007).

Our contribution to the literature can be split into three folds. First, while several studies in the economic growth literature have examined the convergence hypothesis by emphasizing free trade, trade openness, or trade liberalization, none has explored the importance of export diversification in the convergence process. Thus, our study complements the literature by investigating whether export diversification leads to per capita income convergence and thereby narrows the per capita income differences between rich and poor countries. Based on the United Nations Conference on Trade and Development (UNCTAD) ${ }^{2}$ database, we noticed that, though poor countries are rapidly diversifying their exports, they are still lagging behind rich countries.

Second, there is hardly any study examining this research question at the full sample and the subsamples based on income and regions. We divide 95 countries into developed, developing, Asia, Africa, Europe, and Latin America because we noticed a wide variation in export diversification across the levels of income and

2 https://unctadstat.unctad.org/wds/ReportFolders/reportFolders.aspx?sCS_ChosenLang=en. 
regions. In particular, the UNCTAD data shows that developed countries are more diversified in exports, as compared to developing countries. At the regional level, we noticed that the European and Latin America regions are relatively more diversified in exports, as compared to the Asian and African regions. ${ }^{3}$ Thus, the creation of the different groups leads to more insightful evidence about convergence dynamics across these countries.

Third, we do not only examine the income convergence hypothesis by treating export diversification as one of the determinants of income convergence, we also examine whether export diversification plays a role in Total Factor Productivity (TFP) convergence or divergence. Although per capita income is different from TFP, it can be proxied by TFP. Besides, TFP plays an important role in economic growth (see Juhro et al., 2020). To the best of our knowledge, our study is the first to empirically examine export diversification as a determinants of per capita income (output) convergence.

Our results, based on both absolute and conditional convergence tests, reveal that there is no evidence of per capita income and productivity convergence in the full sample, developed, developing, Asia, Africa, Europe, and Latin America samples. However, we find that export diversification has a positive and significant impact on per capita income and TFP. Other factors like human capital, trade openness, domestic credit to the private sector, foreign direct investment, government expenditure consumption, and gross fixed capital formation also affect per capita income and TFP.

Our paper is structured as follows. Section II presents a review of the literature. Section III presents the analytical framework for testing the convergence hypothesis. Data are described in section IV. Section V reports and discusses the results, while Section VI presents the concluding remarks.

\section{REVIEW OF LITERATURE ON CONVERGENCE}

Several studies focus on per capita income (output) convergence in the literature. Table 1 shows a comprehensive list of these studies. A group of studies examined whether trade leads to per income (or output) convergence across the countries (see, Ben-David 1993, 1996; Sachs and Warner, 1995; Bernard and Jones, 1996; Slaughter, 1997; Cyrus 2004; Milanovic, 2006; Choi, 2009; Liu, 2009; Milutinović, 2016; Trofimov and Saad, 2018; among others). For instance, Ben-David (1993, 1996), Sachs and Warner (1995) presented evidence of per capita income convergence through trade for a group of relatively open countries. Rodriguez and Rodrik (2000) and Cyrus (2004) found trade-induced per capita income convergence across countries. Milanovic (2006) found evidence of income convergence during the inter-war trade disintegration period (1919-1939). Similarly, Liu (2009) found that trade induces income convergence. Choi (2009) also found that trade aids income convergence. Milutinović (2016) found that the volume of bilateral trade leads to income convergence. Trofimov and Saad (2018) found that terms of trade influences income convergence in the case of Latin America. They found mixed evidence of income convergence. On the contrary, Bernard and Jones (1996) and

\footnotetext{
3 See Table 1 for more details.
} 
Slaughter (1997) found that international trade does not contribute to the per capita income convergence during pre- and post-liberalization. See Table 1 for a comprehensive literature review on per capita income convergence.

Table 1.

Summary of Literature Review on Convergence

This table provides a summary of the literature. Yes - denotes the convergence, No - denotes divergence and Mixed stands for a mixture of convergence and divergence.

\begin{tabular}{|c|c|c|c|c|}
\hline Authors & Sample period & Countries & Methodology & $\begin{array}{l}\text { Major } \\
\text { findings }\end{array}$ \\
\hline Income growth convergences & & & & Convergence \\
\hline Li et al.(2016) & 1980-2010 & 120 Countries & Fixed effect and GMM & Yes \\
\hline Ha and Lee (2016) & 1970-2011 & Asian countries & Fixed/random effect & No \\
\hline Ceylan and Abiyev (2016) & 1950-2015 & $\mathrm{EU}$ & ESTAR, AESTAR, LM & Yes \\
\hline King and Dobson (2015) & 1950-2009 & Latin America & Unit root test & Yes \\
\hline Chapsaa et al. (2015) & 1995-2013 & European Union (EU) & GMM & Yes \\
\hline Völlmecke et al. (2015) & 2003-2010 & $\mathrm{EU}$ & Markov chain approach & Yes \\
\hline Ghosh et al. (2013) & 1968-2008 & Indian States & Novel approach & No \\
\hline Próchniak and Witkowski (2013) & 1972-2010 & $\mathrm{EU}$ & Bayesian Approach & Yes \\
\hline Serranito (2013) & 1960-2008 & South Europe & Unit root & Mixed \\
\hline Pen (2011) & 1980-2006 & $\mathrm{EU}$ & Unit root & Yes \\
\hline Ayala et al. (2013) & 1950-2011 & Latin America & Unit root & Yes \\
\hline Bandyopadhyay (2012) & 1965-1997 & Indian States & Philips and Sul & Yes \\
\hline Seya et al.(2012) & 1989-2007 & Japan & Bayesian spatial Durbin & Mixed \\
\hline Tunali and Yilanci (2010) & 1950-2006 & MEANA & Unit root test & Mixed \\
\hline Ucar and Guler (2010) & 1991.1-2003.4 & OECD & Seasonal Unit Root tests & Yes \\
\hline Fung(2009) & 1967-2001 & Cross country & GMM & Yes \\
\hline Young et al. (2008) & 1970-1998 & US & 3SLS & Mixed \\
\hline Carmignani et al.(2007) & 1989-2004 & Cross countries & Unit root & Yes \\
\hline Galvão and Gomes (2007) & 1951-1999 & Latin America & Unit root & Yes \\
\hline Guetat and Serranito (2007) & $1960-2000$ & MENA & Unit root & Yes \\
\hline Maasoumi and Wang (2007) & 1965-1995 & OECD \& Non-OECD & Non-parametric regression & Yes \\
\hline Cuñado and Gracia (2006) & 1950-1999 & 43 African & Unit root & Yes \\
\hline Laurini et al. (2005) & 1970-1996 & Brazil & Spline regression & Yes \\
\hline Chowdhury (2004) & 1960-2001 & 9ASEAN & & Mixed \\
\hline Parikh and Shibata (2004) & 1970-1999 & 36 Developing & OLS regression & Yes \\
\hline Wane (2004) & 1965-2002 & 7 WAEMU & & Yes \\
\hline Barro and Sala-i-Martin (2003) & 1965-1995 & 86 Countries & & No \\
\hline Fuente (2003) & 1965-1995 & 19 OECD & & Yes \\
\hline Di Liberto and Symons (2003) & 1950-1990 & $23 \mathrm{OECD}$ & Fixed effects & Yes \\
\hline Mello and Perrelli (2003) & 1960-1985 & 100 Countries & Regression (Solow model) & \\
\hline Mello and Perrelli (2003) & 1960-1995 & 90 Countries & Regression (Solow model) & Yes \\
\hline Stroomer et al. (2003) & $1965-1990$ & 83 countries & FCM algorithm & Mixed \\
\hline $\mathrm{Su}(2003)$ & 1900-1987 & $15 \mathrm{OECD}$ & $\begin{array}{l}\text { Unit root, clustering } \\
\text { algorithm }\end{array}$ & Mixed \\
\hline
\end{tabular}


Table 1.

Summary of Literature Review on Convergence (Continued)

\begin{tabular}{|c|c|c|c|c|}
\hline Authors & Sample period & Countries & Methodology & $\begin{array}{l}\text { Major } \\
\text { findings }\end{array}$ \\
\hline Income growth convergences & & & & Convergence \\
\hline Dobson et al. (2002) & 1960-1990 & Latin America & Semi-parametric approach & Yes \\
\hline McCoskey (2002) & $1960-1990$ & Sub-Saharan Africa & Unit root & No \\
\hline Zhang et al. (2001) & 1952-1997 & China & Unit root test & Yes \\
\hline Nakamura (2001) & $1965-1990$ & 50 Countries & & No \\
\hline Ferreira (2000) & $1970-1986$ & Brazil & OLS & Yes \\
\hline Azomahou et al. (2011) & $1900-2005$ & European Regions & $\begin{array}{l}\text { Semiparametric partially } \\
\text { linear }\end{array}$ & Mixed \\
\hline Smolny (2000) & 1951-1988 & 16 Industrialized & & Yes \\
\hline Murthy and Upkolo (1999) & 1960-1985 & 37 African & Regression (Solow model) & No \\
\hline Murthy and Chien (1997) & 1960-1985 & OECD & Regression (Solow model) & No \\
\hline Andrés et al. (1996) & 1960-1990 & $24 \mathrm{OECD}$ & Regression (Solow model) & No \\
\hline Evans and Karras (1996) & 1950-1990 & 54 Countries & Regression (Solow model) & Yes \\
\hline Nonneman and Vanhoudt (1996) & 1960-1985 & $22 \mathrm{OECD}$ & Regression (Solow model) & Yes \\
\hline Islam (1995) & 1960-1985 & 22 OECD & pooled regression & No \\
\hline Mankiw et al. (1992) & 1960-1985 & 98 countries & Regression (Solow model) & No \\
\hline Mankiw et al. (1992) & 1960-1985 & 22 OECD & Regression (Solow model) & No \\
\hline \multicolumn{5}{|l|}{ Productivity convergence } \\
\hline Rath and Akram(2019) & $1970-2014$ & 73 countries & LM and RALS-LM & Yes \\
\hline Rath, (2019) & 1968-2014 & ASEAN & LM and RALS-LM & Yes \\
\hline Neto and Veiga (2013) & 1970-2009 & 139 countries & GMM & No \\
\hline Kumar and Managi (2012) & 1993-2005 & Indian States & fixed/random effect model & Yes \\
\hline Miller et al. (2002) & 1960-1989 & 83 Countries & Fixed effects & Yes \\
\hline Lee (2009) & 1975-2004 & 25 countries & GMM & Yes \\
\hline \multicolumn{5}{|l|}{ Other convergence } \\
\hline Rath (2016) & $2000-2012$ & 47 Countries & GMM & No \\
\hline Boako (2016) & 2003.1-2014.12 & Africa & Unit root & Yes \\
\hline Chien et al. (2015) & 1994-2002 & China and 5-Asian & Structural break, cointegration & Yes \\
\hline Naryan et al. (2011) & $1985-2008$ & 120 countries & GMM & Mixed \\
\hline
\end{tabular}

These studies have several shortcomings. First, there is no clear evidence in favour of the trade and income convergence hypotheses. The reasons behind this lack of evidence could be the different assumptions regarding the notion of convergence hypothesis, country groups, inclusion of different explanatory variables for economic growth, and different time periods (Azomahou et al., 2011; Dobson et al., 2002; McCoskey, 2002; Mello and Perrelli, 2003; Fuente, 2003; Barro and Sala-i-Martin, 2003; Wane, 2004; Próchniak and Witkowski, 2013; Völlmecke et al., 2015; Chapsaa et al., 2015; Li et al., 2016). Thus, this lack of evidence further motivates us to re-examine the trade and per capita income convergence across countries. Second, the majority of the studies in the literature focus on output convergence but a little attention has been paid to trade and total factor productivity convergence across countries or regions (Miller et al., 2002; 
Lee, 2009; Kumar and Managi, 2012; Neto and Veiga, 2013, Rath and Akram, 2019; Rath, 2019). There are also a few prominent studies that connect the convergence literature to non-economic factors (Narayan et al., 2011; Chien et al., 2015; Rath, 2016; Boako, 2016). Third, the above-reviewed studies have completely ignored the role of export diversification in the trade and income convergence hypotheses. Thus, our study bridges these research gaps by examining the trade, per capita income, and total factor productivity convergence hypotheses by considering the role of export diversification across 95 countries.

\section{ANALYTICAL FRAMEWORK}

The neoclassical growth theory predicts convergence, which is nothing but a transitional growth path or a steady state (Solow, 1956; Swan, 1956). The SolowSwan growth model is based on the assumption of diminishing returns of capital accumulation (Solow, 1956; Swan, 1956). This model infers that the initial differences in per capita income and capital endowments disappear in the long run because of declining growth rates, as countries approach the steady-state position. In the steady state, diminishing returns are compensated by technological progress, which is a primary source of long-run economic growth (Solow, 1956; Swan, 1956). In contrast, the new endogenous growth theories are more relevant to explaining the divergence in long-run economic growth by emphasizing knowledge or human capital accumulation (Barro and Sala-i-Martin, 1995). It is well known in cross-country analysis that convergence depends on the degree of international knowledge spillovers, which allow lower per capita income countries to catch-up with high per capita income countries. The next section examines the notions of $\sigma$ and $\beta$ convergence, following Barro and Sala-i-Martin (1995).

\section{A. $\sigma$ Convergence}

This section outlines the $\sigma$-convergence technique, which shows whether a group of the countries are converging by testing whether the standard deviation of their per capita output is declining over a period of time. We quantify $\sigma$-convergence through the coefficient of variation by taking a logarithm of per capita output of economies. The standard deviation of each country's per capita output is given by:

$$
\text { S. D. }=\sqrt{\frac{1}{n} \sum_{i=1}^{n}\left[\ln \left(y_{i, t}\right)-\ln (\bar{y})\right]^{2}}, \text { where } \ln (\bar{y})=\frac{1}{n} \sum_{i=1}^{n} \ln \left(y_{i, t}\right)
$$

\section{B. Models Specification for Absolute and Conditional Convergence}

To examine the absolute and conditional $(\beta)$ convergence hypotheses, we use a dynamic panel data model (system-GMM) estimator. There are two advantages in using the dynamic panel data model. First, it includes a complete set of countryspecific effects as exogenous variables; the fixed effects specification avoids the omitted variable bias problem, which arises due to the heterogeneity across countries. Second, it takes into account possible endogeneity of the predictors of 
covergence(Castellacci and Archibugi, 2008; Narayan et al., 2011; Rath, 2016). ${ }^{4}$ In this paper, we test the cross-country converbence of per capita income and total factor productivity through the following equation:

$$
\ln \left(y_{i, t}\right)-\ln \left(y_{i, t-\tau}\right)=\beta \ln \left(y_{i, t-\tau}\right)+\delta \ln x_{i, t-\tau}+\mu_{i}+\lambda_{t}+\varepsilon_{i, t}
$$

where $y_{i, t}$ is the per capita income of country $i$ for period $t ; x_{i, t-\tau}$ is a vector of determinants of per capita income growth; $\mu_{i}$ is a country-specific effect; $\lambda_{t}$ is a timespecific constant and $\varepsilon_{i, t}$ is an error term. If $\beta$ coefficient is negative and statistically significant, then it suggests evidence of convergence and vice versa. $x_{i, t-\tau}$ and $\mu_{i}$ are used as a long-run rate convergence of per capita income growth, whereby $\mu_{i}$ indicates the country-specific effect of other factors that are not captured by $x_{i, t-\tau}$. Note that, without $x_{i, t-\tau^{\prime}}$ a negative $\beta$ implies absolute convergence. We can write Eq. (2) as follows:

$$
y_{i, t}=\eta y_{i, t-\tau}+\delta \ln x_{i, t-\tau}+\mu_{i}+\lambda_{t}+\varepsilon_{i, t}
$$

where $\eta=1+\beta$ and $y_{i, t}=\ln y_{i, t}$. We remove the country- and time-specific effects $\left(\mu_{i}\right.$ and $\lambda_{\mathrm{t}}$ ) by differencing Eq. (3) as follows:

$$
y_{i, t}-y_{i, t-\tau}=\eta\left(y_{i, t-\tau}-y_{i, t-2 \tau}\right)+\delta \ln \left(x_{i, t-\tau}-x_{i, t-2 \tau}\right)+\left(\varepsilon_{i, t}-\varepsilon_{i, t-1}\right)
$$

We are unable to estimate Eq. (4) using the ordinary least squares (OLS) method, when both $x_{i, t-\tau}$ and $x_{i, t-2 \tau}$ are endogenous. Moreover, lagged dependent variables are correlated with the composite error term through period $t-\tau$. Therefore, like Arellano and Bond (1991), we take all of the past values of the explanatory variables as instruments in the regression. Since we set $\tau$ to 1, Eq. (4) can be written as:

$$
\ln \left(y_{i, t}\right)-\ln \left(y_{i, t-\tau}\right)=\beta \ln \left(y_{i, t-\tau}\right)+\delta \ln x_{i, t-\tau}+\varepsilon_{i, t}
$$

which we estimate using the system-GMM estimator. To estimate the convergence rate, we set $\lambda=(1+\beta) / \tau$. The vector $x_{i, t-\tau}$ contains macroeconomic variables (i.e. export concentration, trade openness, general government final consumption expenditure, human capital, foreign direct investment, domestic credit to the private sector, and gross fixed capital formation).

\section{DATA}

Our full sample is chosen based on data availability. Our sample include 95 countries, out of which 69 are developing and 26 are developed countries (see, Appendix A). Further, we divide these 95 countries into the Asian, African, European, and Latin American regions. The Asian, African, European, and Latin American regions consists of 16, 24, 25, and 19 countries, respectively. We use annual data on per capita Gross Domestic Product (GDP) (to proxy for per capita income), total factor productivity, export concentration (to proxy for export

4 See these studies for more details of absolute and conditional convergence. 
diversification, which indicates that higher value of export concentration leads to the lower diversification and vice versa), human capital, general government final consumption expenditure, trade openness, foreign direct investment, gross fixed capital formation, and domestic credit to private sector over the period of 1970 to 2010. The determinants of economic growth based on the extended growth theory are chosen following recent works by Kumar and Pacheco (2012), Arazmuradov et al. (2014), Chapsaa et al. (2015), Völlmecke et al. (2015), Li et al. (2016), Iyke (2017, 2018), and Ho and Iyke (2020). The data sources and description of the variables are illustrated in Appendix B.

\section{RESULTS}

Before discussing the convergence test results, we first discuss the correlation among the variables in order to identify potential multicollinearity. Table 2 shows the correlation matrix. We find that most of the variables are correlated by less than $5 \%$ to each other. This implies that there is no evidence of multicollinearity among the explanatory variables.

Table 2.

\section{Correlation Matrix}

This table reports the correlation values between the explanatory variables. The results reported in this table show that there is no exact and perfect correlation between the explanatory variables as values of the same are below 0.50 . Thus, we do are not concerned about multicolinerty issues. Finally, ${ }^{* * *}$, and ${ }^{* *}$ denote the $1 \%$, and $5 \%$ level of significance, respectively.

\begin{tabular}{lccccccc}
\hline Variables & $\begin{array}{c}\text { Export } \\
\text { concentration }\end{array}$ & $\begin{array}{c}\text { Human } \\
\text { capital }\end{array}$ & $\begin{array}{c}\text { Credit to } \\
\text { private } \\
\text { sector }\end{array}$ & $\begin{array}{c}\text { Foreign } \\
\text { direct } \\
\text { investment }\end{array}$ & $\begin{array}{c}\text { Govt. } \\
\text { expenditure }\end{array}$ & $\begin{array}{c}\text { Trade } \\
\text { openness }\end{array}$ & $\begin{array}{c}\text { Gross fixed } \\
\text { capital } \\
\text { formation }\end{array}$ \\
\hline $\begin{array}{l}\text { Export concentration } \\
\text { Human } \\
\text { capital }\end{array}$ & 1.00 & $-0.43^{* * *}$ & 1.00 & & & & \\
$\begin{array}{l}\text { Credit to private } \\
\text { sector }\end{array}$ & $-0.42^{* * *}$ & $0.04^{* * *}$ & 1.00 & & & \\
$\begin{array}{l}\text { Foreign direct } \\
\text { investment }\end{array}$ & $-0.08^{* * *}$ & $0.15^{* * *}$ & $0.12^{* * *}$ & 1.00 & & \\
$\begin{array}{l}\text { Govt. } \\
\text { expenditure }\end{array}$ & $-0.13^{* * *}$ & $0.25^{* * *}$ & $0.30^{* * *}$ & $0.05^{* *}$ & 1.00 & \\
$\begin{array}{l}\text { Trade } \\
\text { openness }\end{array}$ & $-0.07^{* * *}$ & $0.24^{* * *}$ & $0.20^{* * *}$ & $0.45^{* * *}$ & $0.05^{* *}$ & 1.00 & \\
$\begin{array}{l}\text { Gross fixed capital } \\
\text { formation }\end{array}$ & -0.01 & $0.13^{* * *}$ & $0.21^{* * *}$ & $0.17^{* * *}$ & -0.01 & $0.17^{* * *}$ & 1.00 \\
\hline
\end{tabular}

Second, we describe the summary statistics of the variables used in our analysis. Table 3 shows that the average log per capita income values are around 8.70, 10.35, and 8.08 for the full sample, developed and developing countries, respectively. Clearly, the per capita income of the developed countries is higher than that of the developing countries. Similarly, at the regional level, the average log per capita income values are around 10.34, 8.99, 7.28, and 8.62, resepectively, for Europe, 
Asia, Africa, and Latin America. This shows that the African region has the lowest per capita income as compared to the other regions. We also found that the average TFP of the developed countries is around 0.80, whereas that of the developing countries is around 0.53. At the regional levels, Europe, Asia, and Latin America have a relatively higher TFP. In terms of export diversification, we found that the developed countries and Europe are relatively diversified in their exports. Based on the standard deviation, we find evidence of heterogeneity in income across the panels. Table 3 also shows the summary statistics of other variables like human capital, credit to the private sector, trade openness, government consumption expenditure, foreign direct investment, and gross fixed capital formation.

Table 3.

Summary Statistics

This table reports the summary statistics of the variables for the period 1995 to 2017.

\begin{tabular}{|c|c|c|c|c|c|c|c|c|}
\hline \multirow[t]{2}{*}{ Variables } & \multicolumn{2}{|c|}{ Full sample } & \multicolumn{2}{|c|}{ Developed } & \multicolumn{2}{|c|}{ Developing } & \multicolumn{2}{|c|}{ Europe } \\
\hline & Mean & SD & Mean & SD & Mean & SD & Mean & SD \\
\hline lnPer-capita income & 8.70 & 1.52 & 10.35 & 0.73 & 8.08 & 1.25 & 10.34 & 0.74 \\
\hline Total factor productivity & 0.60 & 0.23 & 0.80 & 0.13 & 0.53 & 0.22 & 0.79 & 0.12 \\
\hline Export concentration & 0.29 & 0.20 & 0.14 & 0.09 & 0.34 & 0.20 & 0.13 & 0.07 \\
\hline Human capital & 2.51 & 0.67 & 3.18 & 0.33 & 2.26 & 0.59 & 3.19 & 0.33 \\
\hline Credit to private sector & 54.01 & 44.53 & 94.50 & 46.91 & 38.74 & 32.41 & 93.23 & 45.47 \\
\hline Trade openness & 81.17 & 50.82 & 88.64 & 55.90 & 78.36 & 48.49 & 88.93 & 56.93 \\
\hline Govt. expenditure & 16.12 & 5.59 & 19.52 & 3.31 & 14.85 & 5.73 & 19.36 & 3.27 \\
\hline Foreign direct investment & 4.06 & 6.82 & 5.50 & 10.54 & 3.52 & 4.59 & 5.56 & 10.54 \\
\hline Gross fixed capital formation & 21.90 & 6.10 & 22.19 & 3.73 & 21.78 & 6.80 & 22.21 & 3.65 \\
\hline \multirow[t]{2}{*}{ Observation } & \multicolumn{2}{|c|}{2185} & \multicolumn{2}{|l|}{598} & 1587 & & \multicolumn{2}{|l|}{575} \\
\hline & \multicolumn{2}{|c|}{ Asia } & \multicolumn{2}{|c|}{ Africa } & \multicolumn{2}{|c|}{ Latin America } & & \\
\hline InPer-capita income & 8.99 & 1.23 & 7.28 & 1.04 & 8.62 & 0.70 & & \\
\hline Total factor productivity & 0.58 & 0.19 & 0.49 & 0.22 & 0.59 & 0.20 & & \\
\hline Export concentration & 0.31 & 0.21 & 0.41 & 0.23 & 0.28 & 0.15 & & \\
\hline Human capital & 2.46 & 0.44 & 1.77 & 0.46 & 2.45 & 0.33 & & \\
\hline Credit to private sector & 64.01 & 36.23 & 28.901 & 31.06 & 37.77 & 23.61 & & \\
\hline Trade openness & 102.06 & 78.97 & 66.73 & 27.02 & 66.65 & 29.81 & & \\
\hline Govt. expenditure & 15.02 & 5.69 & 15.42 & 6.95 & 13.29 & 4.33 & & \\
\hline Foreign direct investment & 3.53 & 5.00 & 2.94 & 4.77 & 3.85 & 2.90 & & \\
\hline Gross fixed capital formation & 26.18 & 6.37 & 20.57 & 7.28 & 20.67 & 4.50 & & \\
\hline Observation & 368 & & 552 & & 437 & & & \\
\hline
\end{tabular}

To examine whether export diversification leads to convergence of per capita income and TFP, we check whether per capita income growth across the full sample and the subsamples based on income and region are significantly different in the initial period (i.e.1995). We use a one-sample $t$-test technique to test the mean differences of per capita income across the countries in the initial year. That is, we test the null hypothesis of no mean per capita income difference in the initial period. Similarly, we repeat a one-sample $t$-test for TFP to check the robustness of our results. The results in Table 4 support the rejection of the null hypothesis, 
which implies that the per capita income and TFP growth in 19995 are significantly different across the subsamples.

Table 4.

One Sample $t$-Test for Per-Capita Income and Total Factor Productivity Growth

In this table, we explain the one-sample $t$-test.

\begin{tabular}{lcccccc}
\hline One sample Test & & \multicolumn{2}{c}{ Test value=0 } & \multicolumn{3}{c}{$\begin{array}{c}\text { 95\% confidence } \\
\text { interval of difference }\end{array}$} \\
\hline lnPer-capita income & T & Df & $\begin{array}{c}\text { Sig. } \\
\text { (2-tailed) }\end{array}$ & Mean & Lower & Upper \\
\hline Full sample & 53.89 & 94 & 0.00 & 8.46 & 8.14 & 8.77 \\
Developed & 65.09 & 25 & 0.00 & 10.10 & 9.78 & 10.42 \\
Developing & 51.98 & 68 & 0.00 & 7.83 & 7.53 & 8.13 \\
Europe & 62.59 & 24 & 0.00 & 10.09 & 9.76 & 10.42 \\
Asia & 26.20 & 15 & 0.00 & 8.68 & 7.98 & 9.39 \\
Africa & 32.84 & 23 & 0.00 & 7.06 & 6.61 & 7.50 \\
Latin America & 51.93 & 18 & 0.00 & 8.42 & 8.08 & 8.76 \\
\hline Total factor productivity & & & & & & \\
\hline Full sample & 24.14 & 94 & 0.00 & 0.64 & 0.59 & 0.69 \\
Developed & 33.05 & 25 & 0.00 & 0.80 & 0.76 & 0.85 \\
Developing & 17.83 & 68 & 0.00 & 0.58 & 0.51 & 0.64 \\
Europe & 31.86 & 24 & 0.00 & 0.80 & 0.75 & 0.86 \\
Asia & 13.24 & 15 & 0.00 & 0.62 & 0.52 & 0.73 \\
Africa & 9.69 & 23 & 0.00 & 0.54 & 0.42 & 0.65 \\
Latin America & 10.30 & 18 & 0.00 & 0.68 & 0.54 & 0.82 \\
\hline
\end{tabular}

\section{A. Sigma Convergence}

Next, we estimated sigma convergence of per capita income and TFP using Eq. (1). In Figure 1, we plot the Coefficient of Variation (CV) of per capita income and TFP. From Figure 1, we can see that the CV of per capita income was $131.73 \%$ in 1995 and has increased to $135.80 \%$ in 2002. After, 2002, it has declined to $126.11 \%$ in 2017. We see a similar pattern for the CV of TFP. Overall, the CV of per capita income and TFP indicate aweak evidence of sigma convergence as there is a slight decline in the CV of both indicators from initial year (i.e. 1995) to recent year (i.e. 2017). 
Figure 1.

Coefficient of Variation (CV) in Per Capita Income

This figure has the coefficient of variation in per capita income from 1995 to 2017.

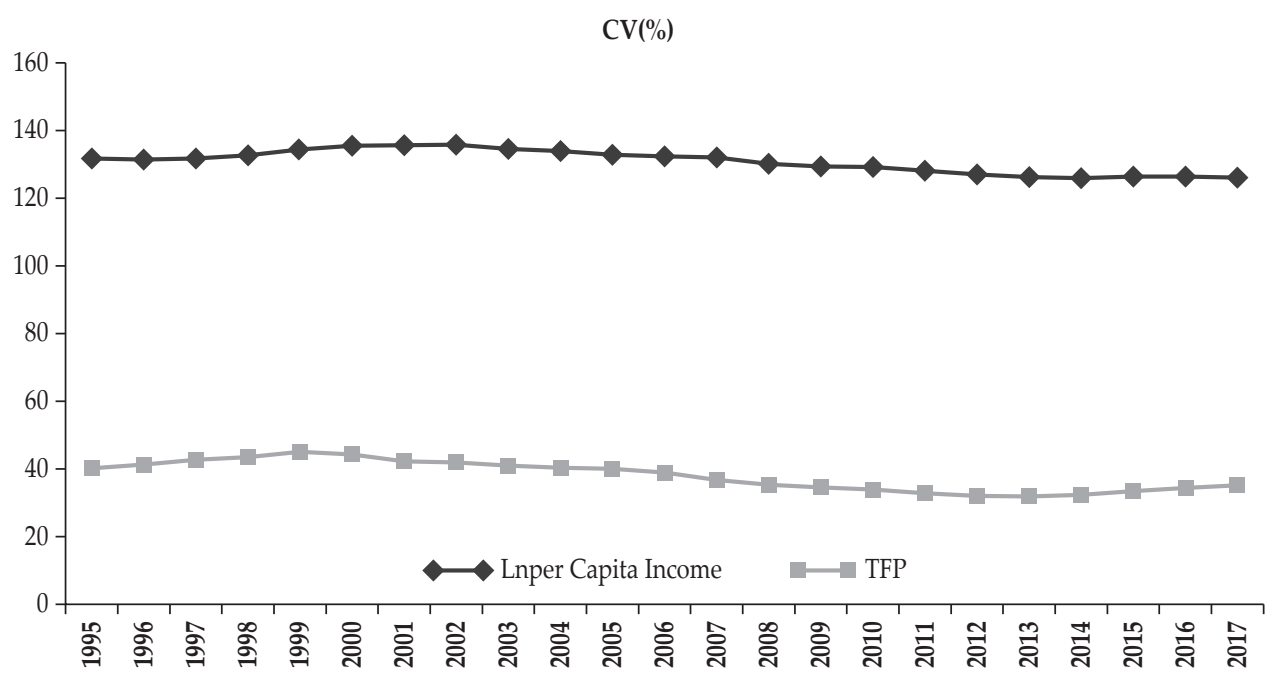

\section{B. Absolute Convergence}

Having discussed the sigma-convergence test results, we now discuss the absolute and conditional beta-convergence test results for full sample and the subsamples, which are reported in Table 5. Before discussing these results, it is essential to understand the economic motivation behind the absolute and conditional convergence of per capita income. On the one hand, absolute convergence is nothing but the different growth patterns of per capita income in the initial period. On the other hand, conditional convergence occurs when the growth of per capita income not only depends on the initial per capita income but also on other factors such as export concentration, human capital, foreign direct investment, trade openness, export diversification, government consumption expenditure, domestic credit to private sector, and gross fixed capital formation. Table 5 shows evidence in support of absolute and conditional divergence of per capita income and TFP for the full sample. The results further indicate the absence of both absolute and conditional convergence in the developed, developing, Asia, Africa, Europe, and Latin America panels. 
Table 5 .

Summary of Convergence Results

This table has results on Absolute Convergence (AC) and Conditional Convergence (CC). Values in parentheses are significance levels.

\begin{tabular}{lll}
\hline Countries/Dependent variables & AC & CC \\
\hline InPer capital income & & \\
\hline Full sample & No $(1 \%)$ & No $(1 \%)$ \\
Developed & No $(1 \%)$ & No $(1 \%)$ \\
Developing & No $(1 \%)$ & No $(1 \%)$ \\
Europe & No $(1 \%)$ & No $(1 \%)$ \\
Asia & No $(1 \%)$ & No $(1 \%)$ \\
Africa & No $(1 \%)$ & No $(1 \%)$ \\
Latin America & No $(1 \%)$ & No $(1 \%)$ \\
\hline Total factor productivity & & \\
\hline Full sample & No $(1 \%)$ & No $(1 \%)$ \\
Developed & No $(1 \%)$ & No $(1 \%)$ \\
Developing & No $(1 \%)$ & No $(1 \%)$ \\
Europe & No $(1 \%)$ & No $(1 \%)$ \\
Asia & No $(1 \%)$ & No $(1 \%)$ \\
Africa & No $(1 \%)$ & No $(1 \%)$ \\
Latin America & No $(1 \%)$ & No $(1 \%)$ \\
\hline
\end{tabular}

Our results presented in Table 6 indicate that the coefficients of initial per capita income are positive and statistically significant at the $1 \%$ level in all the panels, which implies the existence of absolute divergence. This finding implies that the per capita income of developing countries is not growing at a faster rate to catch up with the per capita income of developed countries. Further, we noticed that the initial per capita income affects the income per capita growth positively in developed and developing countries. The magnitude of the impact of the initial per capita income on the income per capita growth for developing countries is larger than for developed countries. This implies that initial per capita income leads to more divergence for developing countries within the group. At the regional level, we found that initial per capita income affects income per capita growth positively in Asia, Africa, Europe, and Latin America. However, the initial per capita coefficient is larger for the Latin American region as compared to Asian, African, and European regions. This outcome suggests that initial per capita income leads to more divergence for the Latin American countries within the group. To check the validity of the model, we applied the Sargan and Autocorrelation (AR) tests. The p-values associated with the Sargan test statistic are mostly greater than 0.10, meaning that we failed to reject the null hypothesis that overidentified restrictions are valid. The AR statistic also revealed robust evidence against autocorrelation at the $1 \%$ level of statistical significance. 
Table 6.

\section{Results of Absolute Convergence Based on Per Capita Income}

This table presents the results of absolute convergence of per-capita income. The diagnostic test statistics like Sargan test and autocorrelation are also presented. Finally, ${ }^{* * * * *}$ and ${ }^{*}$ denote the $1 \%, 5 \%$ and $10 \%$ level of significance, respectively.

\begin{tabular}{lcccc}
\hline Variable & Full sample & Developed & Developing & Europe \\
\hline InInitial per-capita income & $0.98^{* * *}(0.00)$ & $0.95^{* * *}(0.00)$ & $0.99^{* * *}(0.00)$ & $0.96^{* * *}(0.00)$ \\
Constant & $0.22^{* * *}(0.00)$ & $0.48^{* * *}(0.00)$ & $0.08^{* * *}(0.00)$ & $0.47^{* * *}(0.00)$ \\
Sargan test & $94.90(1.00)$ & $26.69(1.00)$ & $68.55(1.00)$ & $-2.83^{* * *}(0.00)$ \\
AR & $0.05(0.95)$ & $1.19(0.23)$ & $-1.60(0.11)$ & $24.89(1.00)$ \\
Countries & 95 & 26 & 69 & 25 \\
Observations & 2090 & 572 & 1518 & 550 \\
\hline Variable & Asia & Africa & Latin America & \\
\hline Initial per-capita income & $0.96^{* * *}(0.00)$ & $0.98^{* * *}(0.00)$ & $0.99^{* * *}(0.00)$ & \\
t-statistics & $0.33^{* * *}(0.00)$ & $0.13^{* * *}(0.00)$ & $0.05^{*}(0.10)$ & \\
Sargan test & $14.56(1.00)$ & $22.96(1.00)$ & $18.49(1.00)$ & \\
AR & $0.07(0.94)$ & $-0.70(0.48)$ & $1.61(0.11)$ & \\
Countries & 16 & 24 & 19 & \\
Observations & 352 & 528 & 418 & \\
\hline
\end{tabular}

To further check the robustness of our results, we use TFP as an alternative measure of per capita output. In Table 7, we observe that the coefficients of initial TFP are positive and statistically significant for the full sample and the subsamples, which indicate an absolute divergence. Also, we find that the initial TFP affects TFP growth relatively more in the developed countries as compared to the developing countries. Moreover, we noticed that the coefficient of initial TFP is relatively larger for Europe and Latin America, implyinh that the initial per capita TFP leads to more divergence within these groups. The AR and Sargan test results showed that our model is free from autocorrelation and that the overidentified restriction is valid in all the sub-panels.

\section{Table 7.}

\section{Results of Absolute Convergence Based on Total Factor Productivity}

This table presents the results of the absolute convergence of total factor productivity growth. The diagnostic test statistics like Sargan test and autocorrelation are also presented. Finally, ${ }^{* * *},{ }^{* *}$ and ${ }^{*}$ denote the $1 \%, 5 \%$ and $10 \%$ level of significance, respectively.

\begin{tabular}{lcccc}
\hline Variable & Full sample & Developed & Developing & Europe \\
\hline InInitial total factor productivity & $0.89^{* * *}(0.00)$ & $0.91^{* * *}(0.00)$ & $0.85^{* * *}(0.00)$ & $0.92^{* * *}(0.00)$ \\
Constant & $0.06^{* * *}(0.00)$ & $0.07^{* * *}(0.00)$ & $0.07^{* * *}(0.00)$ & $0.06^{* * *}(0.00)$ \\
Sargan test & $94.79(1.00)$ & $25.51(1.00)$ & $68.68(1.00)$ & $24.48(1.00)$ \\
AR & $-1.43(0.15)$ & $1.81(0.68)$ & $0.77(0.43)$ & $-1.52(0.13)$ \\
Countries & 95 & 26 & 69 & 25 \\
Observations & 2090 & 572 & 1518 & 550 \\
\hline Variable & Asia & Africa & Latin America & \\
\hline lnInitial total factor productivity & $0.86^{* * *}(0.00)$ & $0.83^{* * *}(0.00)$ & $0.89^{* * *}(0.00)$ & \\
t-statistics & $0.07^{* * *}(0.00)$ & $0.07^{* * *}(0.00)$ & $0.05^{* * *}(0.00)$ & \\
Sargan test & $15.20(1.00)$ & $23.05(1.00)$ & $18.89(1.00)$ & \\
AR & $-1.18(0.23)$ & $1.00(0.31)$ & $-0.42(0.66)$ & \\
Countries & 16 & 24 & 19 & \\
Observations & 352 & 528 & 418 & \\
\hline
\end{tabular}




\section{Conditional Convergence}

We then estimate the conditional convergence using Eq. (5) by applying the systemGMM. The results, which are presented in Table 8, confirmed the divergence of per capita income across all panels. The full sample results show that initial per capita income, export diversification, human capital, credit to the private sector, trade openness, and foreign direct investment gross fixed capital formation are major determinants of income divergence.

Table 8.

\section{Results of Conditional Convergence Based on Per-Capita Income}

This table presents the results on conditional convergence for all the panels. The astericks*,**,** denote the significance level at the $1 \%, 5 \%$, and $10 \%$, respectively.

\begin{tabular}{lcccc}
\hline Variables & Full sample & Developed & Developing & Europe \\
\hline InInitial per-capita income & $0.98^{* * *}(0.00)$ & $0.97^{* * *}(0.00)$ & $0.97^{* * *}(0.00)$ & $0.99^{* * *}(0.00)$ \\
$\Delta$ Export concentration & $-0.05^{* * *}(0.00)$ & $-0.04(0.64)$ & $-0.02^{* * *}(0.00)$ & $-0.04(0.69)$ \\
$\Delta$ Human capital & $0.04^{* * *}(0.00)$ & $0.02(0.44)$ & $0.05^{* * *}(0.00)$ & $0.02(0.64)$ \\
$\Delta$ Credit to private sector & $-0.001^{* * *}(0.00)$ & $-0.0003^{* * *}(0.00)$ & $-0.001^{* * *}(0.00)$ & $-0.001^{* * *}(0.00)$ \\
$\Delta$ Trade openness & $0.001^{* * *}(0.00)$ & $0.0002^{*}(0.06)$ & $0.001^{* * *}(0.00)$ & $0.0002^{* * *}(0.00)$ \\
$\Delta$ Govt. expenditure & $-0.001^{* * *}(0.00)$ & $-0.004^{* * *}(0.00)$ & $-0.001^{* * *}(0.00)$ & $-0.003^{* * *}(0.00)$ \\
$\Delta$ Foreign direct investment & $0.001^{* * *}(0.00)$ & $0.001^{* * *}(0.00)$ & $0.001^{* * *}(0.00)$ & $0.001^{* * *}(0.00)$ \\
$\Delta$ Gross fixed capital formation & $0.002^{* * *}(0.00)$ & $0.002^{* * *}(0.01)$ & $0.003^{* * *}(0.00)$ & $0.002^{* *}(0.09)$ \\
Diagnostic checking & & & & \\
AR & $1.50(0.63)$ & $1.67(0.12)$ & $1.90(0.11)$ & $-1.70(0.87)$ \\
Sargan test & $90.69(1.00)$ & $23.83(1.00)$ & $64.73(1.00)$ & $23.25(1.00)$ \\
\hline Variables & Asia & Africa & Latin America & \\
\hline Initial per-capita income & $0.96^{* * *}(0.00)$ & $0.71^{* * *}(0.00)$ & $0.98^{* * *}(0.00)$ & \\
$\Delta$ Export concentration & $0.19(0.63)$ & $0.12^{* * *}(0.00)$ & $-0.004(0.96)$ & \\
$\Delta$ Human capital & $0.05(0.79)$ & $0.24^{* *}(0.02)$ & $0.03(0.42)$ & \\
$\Delta$ Credit to private sector & $-0.004(0.26)$ & $0.0003(0.21)$ & $-0.002(0.29)$ & \\
$\Delta$ Trade openness & $0.0004(0.93)$ & $0.0002^{* *}(0.03)$ & $0.001^{* *}(0.02)$ & \\
$\Delta$ Govt. expenditure & $-0.005(0.58)$ & $0.001(0.64)$ & $-0.003^{* * *}(0.00)$ & \\
$\Delta$ Foreign direct investment & $0.002^{* * *}(0.00)$ & $-0.003(0.20)$ & $0.002^{* * *}(0.00)$ & \\
$\Delta$ Gross fixed capital formation & $0.003^{* * *}(0.00)$ & $0.001^{* * *}(0.01)$ & $0.004^{* * *}(0.00)$ & \\
Diagnostic checking & & & & \\
AR & $0.13(0.89)$ & $-1.03(0.30)$ & $1.91(0.11)$ & \\
Sargan test & $8.97(1.00)$ & $14.17(1.00)$ & $17.05(1.00)$ & \\
\hline & & &
\end{tabular}

Moreover, we found that export concentration has a negative and significant impact on per capita income growth for the full full sample, developing countries, and African samples. These findings imply that lowering export concentration boosts the per capita income growth in these countries. In contrast, we did not find any significant impact of export concentration on per capita income growth for the developed, European, Asian, and Latin American samples. In addition, human capital affects per capita income growth for the full sample, developing countries, and African samples, whereas it did not have any significant impact for the rest of the samples. Surprisingly, our result revealed that the coefficients 
of domestic credit to the private sector are negative, which implies that domestic credit does not drive per capita income growth convergence. The reason could be that, in some of the countries, as the money markets were liberalized, the interest rates significantly increased, which would mean that the intermediation role of the commercial banks via channelling savings to the private sector for investment and consequently boosting per capita income growth failed to materialize. The other reason might be due to lack of investment opportunities in the sense that, although the countries have witnessed private sector credit growth owing to the liberalization of the financial sector, the credit boom has been directed at personal consumption rather than at making new investments in technologies and in research and development. We also found that government consumption expenditure harms per capita income growth for all samples but Asia and Africa. Thus, consistent with Iradian (2003), this implies a larger government size harms per capita income growth. We found that trade openness promotes per capita income growth in all samples except Asia. Moreover, gross fixed capital formation has a positive and significant impact on per capita growth for all samples. The p-values associated with the Sargan and AR tests, which are also reported in Table 8, indicate that the overidentifying restrictions are valid and that there is no autocorrelation problem in these estimates.

As a robustness check, we re-estimate the Eq. (5) by replacing per capita income with TFP. The results, which are presented in Table 9, suggest that there is evidence of TFP growth divergence for the full sample and the subsamples. This is consistent with the estimates that are based on per capita income growth in Table 8. Likewise, export concentration, human capital, Foreign Direct Investment (FDI), domestic credit to the private sector, trade openness, government consumption expenditure, and gross fixed capital formation are the major factors driving TFP growth. Again, these findings are consistent with the results reported in Table 8, where we found evidence of conditional divergence. In a nutshell, we found strong evidence in favor of absolute and conditional divergence of per capita income and TFP for most of the sub-panels.

Table 9.

Results of Conditional Convergence Based on Total Factor Productivity

This table presents the results on conditional convergence for all the panels. The astericks *,**,*** denote the $1 \%, 5 \%$, and $10 \%$ significance levels, respectively. Finally, the Sargan test statistics and autocorrelation are valid.

\begin{tabular}{lcccc}
\hline Variables & Full sample & Developed & Developing & Europe \\
\hline Initial total factor productivity & $0.88^{* * *}(0.00)$ & $0.68^{* * *}(0.00)$ & $0.85^{* * *}(0.00)$ & $0.74^{* * *}(0.00)$ \\
$\Delta$ Export concentration & $-0.03^{* * *}(0.00)$ & $-0.03(0.70)$ & $-0.02^{* * *}(0.00)$ & $-0.09^{* *}(0.05)$ \\
$\Delta$ Human capital & $0.003^{* *}(0.05)$ & $-0.08^{* * *}(0.00)$ & $0.04^{*}(0.07)$ & $-0.06^{* * *}(0.01)$ \\
$\Delta$ Credit to private sector & $-0.0001^{* * *}(0.00)$ & $-0.008(0.91)$ & $-0.0002^{* * *}(0.00)$ & $-0.0001(0.28)$ \\
$\Delta$ Trade openness & $0.0002^{* * *}(0.00)$ & $0.0001(0.46)$ & $0.0004^{* * *}(0.00)$ & $0.00003(0.82)$ \\
$\Delta$ Govt. expenditure & $-0.0005^{* * *}(0.01)$ & $0.003^{* *}(0.02)$ & $-0.001^{* * *}(0.00)$ & $0.002(0.30)$ \\
$\Delta$ Foreign direct investment & $-0.0002(0.57)$ & $0.00005(0.55)$ & $0.0003^{* * *}(0.00)$ & $-0.0001(0.16)$ \\
$\Delta$ Gross fixed capital formation & $0.00^{* * *}(0.00)$ & $0.01^{* * *}(0.00)$ & $0.002^{* * *}(0.00)$ & $0.004^{* * *}(0.00)$ \\
Diagnostic checking & & & & \\
AR & $0.82(0.41)$ & $-1.12(0.25)$ & $0.96(0.33)$ & $-1.06(0.28)$ \\
Sargan test & $89.87(1.00)$ & $21.40(1.00)$ & $62.89(1.00)$ & $20.43(1.00)$ \\
\hline
\end{tabular}


Table 9.

Results of Conditional Convergence Based on Total Factor Productivity (Continued)

\begin{tabular}{lccc}
\hline Variables & Asia & Africa & Latin America \\
\hline Initial per-capita income & $0.51^{* * *}(0.00)$ & $0.73^{* * *}(0.00)$ & $0.88^{* * *}(0.00)$ \\
$\Delta$ Export concentration & $-0.75(0.40)$ & $-0.05^{* * *}(0.00)$ & $-0.04(0.35)$ \\
$\Delta$ Human capital & $0.07(0.27)$ & $-0.02(0.56)$ & $0.01(0.79)$ \\
$\Delta$ Credit to private sector & $-0.001^{* * *}(0.00)$ & $-0.001^{* * *}(0.00)$ & $-0.0001(0.44)$ \\
$\Delta$ Trade openness & $0.001(0.14)$ & $-0.002^{* *}(0.02)$ & $0.001^{* *}(0.03)$ \\
$\Delta$ Govt. expenditure & $-0.004(0.27)$ & $-0.0004^{* * *}(0.00)$ & $-0.002^{*}(0.08)$ \\
$\Delta$ Foreign direct investment & $0.001(0.47)$ & $0.0004^{* *}(0.03)$ & $0.0001(0.65)$ \\
$\Delta$ Gross fixed capital formation & $0.005^{* * *}(0.01)$ & $0.001^{* *}(0.04)$ & $0.003^{* * *}(0.00)$ \\
Diagnostic checking & & & \\
AR & $0.13(0.89)$ & $0.99(0.31)$ & $0.32(0.74)$ \\
Sargan test & $8.97(1.00)$ & $16.57(1.00)$ & $16.86(1.00)$ \\
\hline
\end{tabular}

Several studies (see Devpura and Narayan, 2020; Haroon and Rizvi, 2020; Iyke, 2020a,b; Mishra et al., 2020; Narayan, 2020a; Narayan, Devpura, and Hua, 2020; Narayan, Phan, and Liu, 2020; Phan and Narayan, 2020; Prabheesh et al., 2020; Rath, and Akram, 2020; Salisu and and Akanni, 2020; Vidya and Prabheesh, 2020; Salisu and Sikiru, 2020; among others) argued that global markets and economies have been disrupted by the coronavirus pandemic. Recent studies have also shown that exchange rate market bubble activity has increased due to COVID-19 (Narayan, 2020b) and exchange rates have become more resilent due to the pandemic (Narayan, 2020c). We expect this disruption in global economic activities to have a significant impact on per capita income and TFP convergence across countries. However, we are not able to test this due to lack of sufficient data. We leave this hypothesis for future research.

\section{CONCLUSIONS}

This paper examines the effect of international trade on the convergence of per capita income by emphasizing the role of export diversification. While the traditional export-led growth hypothesis emphasizes more on exports, it does not identify the role of exports in growth convergence across countries. The novelty of our paper was to examine the impact of export diversification on per capita income convergence. This research question was important from the perspective of lower-income countries' point of view as these countries are diversifying their export commodity baskets to gain from international trade. If the per capita income growth of poor countries catches up with the rich countries through higher export diversification then poor countries should emphasize trade diversification. We examined this idea using annual data from 1995 to 2017 for 95 countries belonging to both developed and developing countries.

The sigma convergence test results clearly indicated a weak per capita income and TFP convergence. Further, the absolute convergence test results revealed that per capita income has diverged in most of the panels, namely the full sample, 
developed, developing, Asia, Africa, Europe, and Latin America. The conditional convergence test results also showed per capita income divergence for the full sample and the subsamples. In addition, our results clearly revealed that export diversification is one of the key factors that lead to per capita income divergence for both the full sample and the subsamples (based on income and regions).

Acknowledgments: The authors thank the Managing Editor Professor Paresh Kumar Narayan and two anonymous referees for providing valuable suggestions, which substantially improved this paper. The usual disclaimer applies.

\section{REFERENCES}

Acemoglu, K.D., \& Zilibotti, F. (1997). Was Promentheus Unbound by chance? Risk Diversification and Growth. Journal of Political Economy, 105, 709-751.

Agosin, M.R. (2007). Export Diversification and Growth in Emerging Economies (Working Paper, No 233). Departmento de Economia, Universidad de Chile.

Akram, V., \& Rath, B.N. (2017). Export Diversification and Sources of Growth in Emerging Market Economies. Global Economy Journal, 17, 1-13.

Ali, A.,\& Siegel. (1991). Is Export Diversification The Best Way to Achieve Export Growth and Stability? A Look at Three African Countries (World Bank Working Papers No. 729). World Bank, 1991.

Al-Marhubi, F. (2000). Export Diversification and Growth: An Empirical Investigation. Applied Economics Letters, 7, 559-562.

Andrés, J., Doménech, R., \& Molinas, C. (1996). Macroeconomic Performance and Convergence in OECD Countries. European Economic Review, 40, 1683-1704.

Arazmuradov, A., Martini, G., \& Scotti, D. (2014). Determinants of Total Factor Productivity in Former Soviet Union Economies: A Stochastic Frontier Approach. Economic Systems, 38, 115-135.

Arellano, M., \& Bond, S. (1991). Some Tests of Specification for Panel Data: Monte Carlo Evidence and An Application to Employment Equations. Review of Economic Studies, 58, 277-297.

Arip, M.A., Yee, L.S., \& Karim, B.A. (2010). Export Diversification and Economic Growth in Malaysia'. Munich Personal RePEc Archive. http://mpra.ub.unimuenchen.de/20588/

Ayala, A., Cunado, J., \& Alana, L.A.G. (2013). Real Convergence, Empirical Evidence for Latin America. Applied Economics, 22, 3220-3229.

Azomahou, T.T., Ouardighi, J.E., Van, P.N., \& Pham, T.K.C., (2011). Testing Convergence of European Regions: A Semiparametric Approach. Economic Modelling, 28, 1202-1210.

Balaguer, J., \& Cantavella-Jordá, M. (2004). Export Composition and Spanish Economic Growth: Evidence from the 20th Century. Journal of Policy Planning, 26, 165-179.

Baldwin, R.E. (1992). Measurable Dynamic Gains from Trade. Journal of Political Economy, 100, 162-74

Bandyopadhyay, S. (2012). Convergence Clubs in Incomes Across Indian States: Is There Evidence of A Neighbors Effect? Economics Letters, 116, 565-570. 
Barro, R.J., \& Sala-i-Martin, X. (2003). Economic Growth. The MIT Press, Cambridge, London.

Barro, R.J., \& Sala-i-Martin, X. (1995). Economic Growth. Fourth ed. MIT Press, New York.

Baumol, W.J. (1986). Productivity Growth, Convergence, and Welfare: What the Long-Run Data Show. The American Economic Review, 76, 1072-1085.

Ben-David D. (1993). Equalizing Exchange, Trade Liberalization and Income Convergence. Quarterly Journal of Economics, 108, 653-679.

Ben-David D. (1996). Trade and Convergence Among Countries. Journal of International Economics, 40, 279-298.

Ben-David D., \& Loewy M.B. (1998). Free Trade, Growth, and Convergence. Journal of Economic Growth, 3, 143-170.

Bernard, A., \& Jones, C. (1996). Productivity Across Industries and Countries: Time Series Theory and Evidence. The Review of Economics and Statistics, 78, 135-46

Berthélemy, J.C., \& Söderling, L. (2001). The Role of Capital Accumulation, Adjustment and Structural Changes for Economic Take-Off, Empirical Evidence from African Growth Episodes', World Development, 29, 323-343.

Berthélemy, J.C., \& Chauvin, S. (2000). Structural Changes in Asia and Growth Prospects After The Crisis (Working paper no. 00-09). CEPII.

Boako, G., \& Alagidede, P. (2016). African Stock Markets Convergence, Regional and Global Analysis. Finance Research Letters, 000, 1-5.

Carmignani, F. (2007). A Note on Income Converge Effects in Regional Integration Agreements. Economics Letters, 94, 361-366.

Castellacci, F., \& Archibugi, D. (2008). The Technology Clubs, The Distribution of Knowledge Across Nations. Research Policy, 37, 1659-1673.

Ceylan, R., \& Abiyev, V. (2016). An Examination of Convergence Hypothesis for EU-15 Countries. International Review of Economics and Finance, 45, 96-105.

Chapsaa, X., Tsananab, E., \& Katrakilidisb, C. (2015). Growth and convergence in the EU-15: More evidence from the Cohesion Countries. Procedia Economics and Finance, 33, 55- 63.

Chatterjee, P., \& Shukayev. M. (2012). A stochastic Dynamic Model of Trade And Growth: Convergence and Diversification. Journal of Economic Dynamics Control, 36, 416-432.

Chien M.S., Lee C.C., Hu, T.C., \& Hu, H.T. (2015). Dynamic Asian Stock Market Convergence: Evidence from Dynamic Cointegration Analysis among China and ASEAN-5. Economic Modelling, 51, 84-98.

Chowdhury, K. (2004). Convergence of Per Capita GDP Across SAARC Countries (University of Wollongong Economics Working Paper Series 2004, WP 04-07). University of Wollongong.

Cuñado J., \& Pérez de Gracia, F. (2006). Real convergence in Africa in the secondhalf of the $20^{\text {th }}$ century. Journal of Economics and Business, 58, 153-167.

Cyrus, T. (2004). Does convergence cause trade, or does trade cause convergence? Journal of International Trade and Economic Development, 13, 397-418.

Deardorff, A.V. (2001). Rich and Poor Countries in Neoclassical Trade and Growth. The Economic Journal, 111, 277-94.

Deardorff, A.V. (1986). Firless Firwoes: How Preferences Can Interfere with The Theorems of International Trade. Journal of International Economics, 20, 131-142. 
Dennis A.C., \& Shepherd B.A. (2007). Trade Costs, Barriers to Entry, and Export Diversification in Developing Countries (Policy Research Working Paper 4368). The World Bank.

Devpura, N., \& Narayan, P.K. (2020). Hourly Oil Price Volatility: The Role of COVID-19. Energy Research Letters, 1, 13683. https://doi.org/10.46557/001c.13683

Di Liberto, A., \& Symons, J. (2003). Some Econometric Issues in Convergence Regressions. The Manchester School, 71, 293-307.

Dobson, S., \& Ramlogan, C. (2002). Economic Growth and Convergence in Latin America. Journal of Development Studies, 38, 83-104.

Evans, P., \& Karras, G. (1996). Convergence Revisited. Journal of Monetary Economics, 37, 249265.

Felbermayr, G.J. (2005). Dynamic Panel Data Evidence on The Trade-Income Relation. Review of World Economics, 141, 583-611.

Ferreira, A. (2000). Convergence in Brazil, Recent Trends and Long-Run Prospects. Applied Economics, 32, 479-489.

Fuente, D.L.A. (2003). Convergence Equations and Income Dynamics: The Sources of OECD Convergence 1970-1995. Economica, 70, 655-671.

Fung, M.K. (2009). Domestic Credit to Private Sector and Economic Growth: Convergence or Divergence? Journal of International Money and Finance, 28, 56-67.

Galvão Jr F.A., \& Gomes, R. (2007). Convergence or Divergence in Latin America? A Time Series Analysis. Applied Economics, 39, 1353-1360.

Ghosh, M., Ghoshray, A., \& Malki, I. (2013). Regional Divergence and Club Convergence in India. Economic Modelling, 30, 733-742.

Grossman, G., \& E. Helpman. (1991). Innovation and Growth in The Global Economy. Cambridge, MA: The MIT Press.

Guetat I., \& Serranito F. (2007). Income Convergence within The MENA Countries: A Panel Unit Root Approach. The Quarterly Review of Economics and Finance, 46, 685-706.

Ha, J., \& Lee, S.H. (2016). Demographic Dividend and Asia's Economic Convergence Towards The US. The Journal of the Economics of Ageing.

Hammouda, H.B., Karingi, S.N., Njuguna, A.E., \& Jallab, M.S. (2010). Growth, Productivity and Diversification in Africa. Journal of Productivity Analysis, 33, 125-146.

Haroon, O., \& Rizvi, S.A.R. (2020). Flatten The Curve and Stock Market LiquidityAn Inquiry into Emerging Economies, Emerging Markets Finance and Trade, 56, 2151-2161. https://doi.org/10.1080/1540496X.2020.1784716.

Helpman, E., \& Krugman, P.R. (1985). Market Structure And Foreign Trade: Increasing Returns, Imperfect Competition, and The International Economy. Cambridge, MIT Press.

Herzer, D., \& Lehman, N. (2006). What Does Export Diversification Do For Growth? An Econometric Analysis. Applied Economic Letters, 38, 1825-1838.

Ho, S. Y., \& Iyke, B. N. (2020). The Determinants of Economic Growth in Ghana: New Empirical Evidence. Global Business Review, 21, 626-644.

Im, K.S., Pesaran, M.H., \& Shin, Y. (2003). Testing for Unit Roots in Heterogeneous Panels. Journal of Econometrics, 115, 53-74. 
Iradian, G. (2003). Armenia: The Road to Sustained Rapid Growth Cross-Country Evidence (IMF Working Paper No. 03/11). International Monetary Fund, Washington D. C.

Islam, N. (1995). Growth Empirics, A Panel Data Approach. Quarterly Journal of Economics, 110, 1127-1170.

Iyke, B. N. (2017). Does Trade Openness Matter for Economic Growth in The CEE Countries? Review of Economic Perspectives, 17, 3-24.

Iyke, B. N. (2018). The Real Effect of Currency Misalignment On Productivity Growth: Evidence From Middle-Income Economies. Empirical Economics, 55, 1637-1659.

Iyke, B.N. (2020a). COVID-19: The Reaction of US Oil And Gas Producers To The Pandemic. Energy Research Letters, 1, 13912. https://doi.org/10.46557/001c.13912

Iyke, B.N. (2020b). The Disease Outbreak Channel of Exchange Rate Return Predictability: Evidence from COVID-19, Emerging Markets Finance and Trade, 56, 2277-2297. https://doi.org/10.1080/1540496X.2020.1784718.

Juhro, S. M., Narayan, P. K., Iyke, B. N., \& Trisnanto, B. (2020). Is There A Role for Islamic Finance and R\&D In Endogenous Growth Models in The Case of Indonesia? Pacific-Basin Finance Journal. https://doi.org/10.1016/j. pacfin.2020.101297.

King, A., \& Dobson, C.R. (2015). International Income Convergence: Is Latin America Actually Different? Economic Modelling, 49, 212-222.

Kumar, S., \& Managi, S. (2012). Productivity and Convergence in India: A StateLevel Analysis. Journal of Asian Economics, 23, 548-559.

Kumar, S., \& Pacheco, G. (2012). What Determines The Long Run Growth Rate in Kenya? Journal of Policy Modelling, 34, 705-718.

Laurini, M., Andrade, E., \& Pereira, P.L.V. (2005). Income Convergence Clubs for Brazilian Municipalities: A Non-Parametric Analysis. Applied Economics, 37, 2099-2118.'

Leamer, E.E., \& Levinsohn, J. (1996). International trade theory: The evidence in Ronald W. Jones and Peter B. Kenen, (eds. Handbook of Inetrnationl Economics, 3).

Lederman, D.W.F., \& Maloney (2007). Trade structure and growth in natural resources: Neither curse nor destiny, (ed. Daniel Lederman and William Maloney., pp. 1539). Washington DC, World Bank and Stanford University Press.

Lee, J. (2009). Trade, FDI, and Productivity Convergence: A Dynamic Panel Data Approach in 25 Countries. Japan and the World Economy, 21, 226-238.

Li, K.W., Zhou, X., \& Pan Z. (2016). Cross-Country Output Convergence and Growth: Evidence from Varying Coefficient Nonparametric Method. Economic Modelling, 55, 32-41.

Liu, X. (2009). Trade and Income Convergence: Sorting Out The Causality. The Journal of International Trade E Economic Development, 18, 169-195.

Maasoumi E., \& Wang L. (2007). Economic Reform, Growth and Convergence in China. Econometrics Journal, 10, 1-21.

Mankiw, N.G., Romer, D., \& Weil, D.N. (1992). A Contribution to The Empirics of Economic Growth. Quarterly Journal of Economics, 107, 407-437.

Mau, K., (2015). Export Diversification and Income Differences Reconsidered: The Extensive Product Margin in Theory. Review of World Economics, 152, 351-381. 
McCoskey, S.K. (2002). Convergence in Sub-Saharan Africa: A Nonstationary Panel Data Approach. Applied Economics, 34, 819-829.

Mello, M. \& Perrelli, R. (2003). Growth Equations: A Quantile Regression Exploration. The Quarterly Review of Economics and Finance, 43, 643-667.

Milanovic, B. (2006). Global income inequality: What it is and why it matters. Policy Research (Working Paper; No. 3865). World Bank, Washington, DC. World Bank. https://openknowledge.worldbank.org/handle/10986/8344 License: CC BY 3.0 IGO.

Miller, S.M., \& Upadhyay, M.P. (2002). Total Factor Productivity and The Convergence Hypothesis. Journal of Macroeconomics, 24, 267-286.

Milutinović, S. (2016). The Effects of International Trade on Income Convergence of The European Union Member States. Industrija, 44. https://doi.org/10.5937/ industrija44-9005.

Mishra, A.K., Rath, B.N., and Dash, A.K. (2020). Does The Indian Financial Market Nosedive Because of The COVID-19 Outbreak, in Comparison to After Demonetisation and The GST? Emerging Markets Finance and Trade, 56, 21622180; https://doi.org/10/1080/1540496X.2020.1785425.

Murthy, N.R.V., \& Chien, I.S. (1997). The Empirics of Economic Growth for OECD Countries: Some New Findings. Economics Letters, 55, 425-429.

Murthy, N.R.V., \& Upkolo, V. (1999). A Test of The Conditional Convergence Hypothesis: Econometric Evidence from African Countries. Economics Letters, $65,249-253$.

Nakamura, H. (2001). An Empirical Reexamination of The Solow Growth Model. Journal of the Japanese and International Economics, 15, 323-340.

Narayan, P. K. (2020a). Oil Price News and COVID-19-Is There Any Connection? Energy Research Letters, 1, 13176. https://doi.org/10.46557/001c.13176

Narayan, P. K. (2020b). Did Bubble Activity Intensify During COVID-19? Asian Economics Letters,1. https://doi.org/10.46557/001c.17654

Narayan, P. K. (2020c). Has COVID-19 Changed Exchange Rate Resistance to Shocks? Asian Economics Letters, 1. https://doi.org/10.46557/001c.17389

Narayan, P. K., Devpura, N., \& Hua, W. (2020). Japanese Currency and Stock Market-What Happened during The COVID-19 Pandemic?. Economic Analysis and Policy, 68, 191-198.

Narayan, P. K., Phan, D. H. B., \& Liu, G. (2020). COVID-19 Lockdowns, Stimulus Packages, Travel Bans, and Stock Returns. Finance Research Letters, 101732. https://doi.org/10.1016/j.frl.2020.101732.

Narayan, P.K., Sagarika, M., \& Narayan, S. (2011). Do Market Capitalization and Stocks Traded Converge? New Global Evidence. Journal of Banking and Finance, .35, 2771-2781.

Neto, D.G., \& Veiga, F.J. (2013). Financial Globalization, Convergence and Growth: The Role of Foreign Direct Investment. Journal of International Money and Finance, 37, 161-186.

Nonneman, W., \& Vanhoudt, P. (1996). A Further Augmentation of The Solow Model and The Empirics of Economic Growth for OECD Countries. Quarterly Journal of Economics, 111, 943-953.

Parikh, A., \& Shibata, M. (2004). Does trade liberalization accelerate convergence 
in per capita incomes in developing countries? Journal of Asian Economics, $15,33-48$.

Pen, Y.L. (2011). A Pair-Wise Approach to Output Convergence between European Regions. Economic Modelling, 28, 955-964.

Phan, D.H.B., \& Narayan, P.K. (2020). Country Responses and The Reaction of The Stock Market to COVID-19-A Preliminary Exposition, Emerging Markets Finance and Trade, 56, 2138-2150.https://doi.org/10.1080/1540496X.2020.1784719. Prabheesh, K.P., Padhan, R., \& Garg, B. (2020). COVID-19 and The Oil Price-Stock Market Nexus: Evidence from Net Oil-Importing Countries. Energy Research Letters, 1, 13745. https://doi.org/10.46557/001c.13745.

Próchniak, M., \& Witkowski, B. (2013). Time Stability of The Beta Convergence Among EU Countries: Bayesian Model Averaging Perspective. Economic Modelling, 30, 322-333.

Rath, B.N. (2016). Does The Digital Divide Across Countries Lead to Convergence? New International Evidence. Economic Modelling, 58, 75-82.

Rath, B.N., \& Akram, V. (2017). Export Diversification and Total Factor Productivity Growth in Case Of South Asian Region. Journal of Social and Economic Development, 19, 196-210.

Rath, B.N. (2019). Does Total Factor Productivity Converge among Asean Countries? Bulletin of Monetary Economics and Banking, 21, 477 - 494.

Rath, B.N., \& Akram, V. (2019). A Reassessment of Total Factor Productivity Convergence: Evidence from Cross-Country Analysis. Economic Modelling, 82, 87-98.

Rath, B.N., \& Akram, V. (2020). Does COVID-19 Outbreak Cause Spot Electricity Price Discovery in India? Journal of Public Affairs, https://doi.org/10.1002/ pa.2439.

Romer, P.M. (1990). Endogenous technological change. Journal of Political Economy, 98,5 . The problem of development, A conference of the institute for the study of free enterprise systems, S71-S102.

Rossini, G., \& Burattoni, M. (1996). Trade and Convergence between Rich and Developing Countries: Some Empirical Evidence on Macro Determinants of Specialization. Weltwirtschaftliches Archiv, 132, 75-96.

Sachs, J.D., \& Warner, A. (1995). Economic Reform and The Process of Global Integration. Brookings Papers on Economic Activity, 1, 1-118.

Salisu, A.A., \& Akanni, L.O. (2020) Constructing A Global Fear Index for COVID-19 Pandemic. Emerging Markets Finance and Trade, 56, 2213-2230. https://doi.org/10 .1080/1540496X.2020.1785424

Salisu, A. A., \& Sikiru, A. A. (2020) Pandemics and The Asia-Pacific Islamic Stocks. Asian Economics Letters, 1. https://doi.org/10.46557/001c.17413.

Samuelson, P. (1948). International Trade and The Equalization of Factor Prices. Economic Journal, 58, 63-184.

Serranito, F. (2013). Heterogeneous Technology and The Technological CatchingUp Hypothesis: Theory and Assessment in The Case of MENA Countries. Economic Modelling, 30, 685-697.

Seya, H., Tsutsumi, M., \& Yamagata, Y. (2012). Income Convergence in Japan: A Bayesian Spatial Durbin Model Approach. Economic Modelling, 29, 60-71.

Slaughter, M.J. (1997). Per Capita Income Convergence and The Role of International 
Trade. American Economic Review, 87, 194-199.

Slaughter, M.J. (1995). The Antebellum Transportation Revolution and Factor-Price Convergence (NBER Working Paper No. W5303). National Bureau of Economic Research. https://ssrn.com/abstract=225367.

Slaughter, M.J (2001). Trade Liberalization and Per Capita Income Convergence: A Difference-in- Differences Analysis. Journal of International Economics, 55, 203-228.

Smolny, W. (2000). Post-war Growth, Productivity Convergence and Reconstruction. Oxford Bulletin of Economics and Statistics, 62, 589-606.

Solow, R.M., (1956). A Contribution to Theory of Economic Growth. Quarterly Journal Of Economics, 70,65-64.

Song, E.Y. (2014). Trade and Speed of Convergence. Review of Development Economics, 18, 1-12.

Stehrer, R., \& Wörz, J. (2003). Technological Convergence and Trade Patterns. Review of World Economics, 139, 191-219.

Stroomer, C.N., \& Giles, D.E.A. (2003). Income Convergence and Trade Openness, Fuzzy Clustering and Time Series Evidence' (Econometrics Working Paper EWP0304). Department of Economics, University of Victoria.

Su, J.J. (2003). Convergence Clubs among 15 OECD Countries. Applied Economics Letters, 10, 113-118.

Swan, T.W. (1956). Economic Growth and Capital Accumulation. Economic Record, 32, 334-361.

Trofimov, I.D. \& Saad, K.Y. (2018). Income terms of trade and economic convergence: Evidence from Latin America (MPRA Paper No. 87598). Munich Personal RePEc Archive. https://mpra.ub.uni-muenchen.de/87598/.

Tunali, C.B., \& Yilanci, V. (2010). Are Per Capita Incomes of MENA Countries Converging or Diverging? Physica, 389, 4855-4862.

Ucar, N., \& Guler, H. (2010). Testing Stochastic Income Convergence in Seasonal Heterogeneous Panels. Economic Modelling, 27, 422-431.

Vidya, C. T., \& Prabheesh, K.P. (2020) Implications of COVID-19 Pandemic on The Global Trade Networks. Emerging Markets Finance and Trade, 56, 2408-2421. https://doi.org/10.1080/1540496X.2020.1785426.

Vollmecke, D, Bjorn, J., \& Philipp, M. (2015). FDI, Human Capital and Income Convergencemdash: Evidence for European Regions. Economic Systems, 40, 288-307.

Wane, A.A., (2004). Growth and Convergence in WAEMU Countries (Working Paper, No. 198). IMF, Washington D.C.

Young, A.T., Higgins, M.J., \& Levy, D. (2008). Sigma Convergence Versus Beta Convergence: Evidence from U.S. County-Level Data. Journal of Money, Credit and Banking, 40, 1083-1093

Zhang, Z., Liu, A., \& Yao, S. (2001). Convergence of China's Regional Incomes 1952-1997. China Economic Review, 12, 243-258. 
Appendix A.

List of Countries

\begin{tabular}{|c|c|c|c|c|}
\hline \multicolumn{2}{|c|}{ Full sample } & & \multirow{2}{*}{\multicolumn{2}{|c|}{$\begin{array}{l}\text { Angola, Argentina, Armenia, } \\
\text { Bahrain, Barbados, Benin, Bolivia, } \\
\text { Botswana, Brazil, Burkina Faso, } \\
\text { Burundi, Cameroon, Central African } \\
\text { Republic, Chile, China, Colombia, } \\
\text { Costa Rica, Cote d Ivoire, Dominican } \\
\text { Republic, Ecuador, Egypt, Eswatini, } \\
\text { Gabon, Guatemala, Honduras, India, } \\
\text { Indonesia, Iran, Israel, Jamaica, } \\
\text { Jordan, Kazakhstan, Kenya, Kuwait, } \\
\text { Kyrgyzstan, Malaysia, Mauritius, } \\
\text { Mexico, Mongolia, Morocco, } \\
\text { Mozambique, Namibia, Nicaragua, } \\
\text { Niger, Nigeria, Panama, Paraguay, } \\
\text { Peru, Philippines, Qatar, Republic } \\
\text { of Moldova, Russian Federation, } \\
\text { Rwanda, Saudi Arabia, Senegal, } \\
\text { Sierra Leone, Singapore, South } \\
\text { Africa, Sri Lanka, Sudan, Tajikistan, } \\
\text { Thailand, Togo, Tunisia, Turkey, } \\
\text { Ukraine, Uruguay, Venezuela, } \\
\text { Zimbabwe }\end{array}$}} \\
\hline \multicolumn{2}{|c|}{$\begin{array}{l}\text { Angola, Argentina, Armenia, Australia, } \\
\text { Austria, Bahrain, Barbados, Benin, Bolivia, } \\
\text { Botswana, Brazil, Bulgaria, Burkina Faso, } \\
\text { Burundi, Cameroon, Central African } \\
\text { Republic, Chile, China, Colombia, Costa } \\
\text { Rica, Cote d Ivoire, Croatia, Czechia, } \\
\text { Denmark, Dominican Republic, Ecuador, } \\
\text { Egypt, Eswatini, Finland, France, Gabon, } \\
\text { Germany, Greece, Guatemala, Honduras, } \\
\text { Hungary, Iceland, India, Indonesia, Iran, } \\
\text { Ireland, Israel, Italy, Jamaica, Japan, Jordan, } \\
\text { Kazakhstan, Kenya, Kuwait, Kyrgyzstan, } \\
\text { Luxembourg, Malaysia, Mauritius, Mexico, } \\
\text { Mongolia, Morocco, Mozambique, Namibia, } \\
\text { Netherlands, New Zealand, Nicaragua, } \\
\text { Niger, Nigeria, Norway, Panama, Paraguay, } \\
\text { Peru, Philippines, Poland, Portugal, Qatar, } \\
\text { Republic of Moldova, Romania, Russian } \\
\text { Federation, Rwanda, Saudi Arabia, Senegal, } \\
\text { Sierra Leone, Singapore, South Africa, Spain, } \\
\text { Sri Lanka, Sudan, Sweden, Switzerland, } \\
\text { Tajikistan, Thailand, Togo, Tunisia, Turkey, } \\
\text { Ukraine, United Kingdom, Uruguay, } \\
\text { Venezuela, Zimbabwe }\end{array}$} & $\begin{array}{l}\text { Australia, } \\
\text { Austria, } \\
\text { Bulgaria, } \\
\text { Croatia, Czechia, } \\
\text { Denmark, } \\
\text { Finland, France, } \\
\text { Germany, } \\
\text { Greece, } \\
\text { Hungary, } \\
\text { Iceland, Ireland, } \\
\text { Italy, Japan, } \\
\text { Luxembourg, } \\
\text { Netherlands, } \\
\text { New Zealand, } \\
\text { Norway, Poland, } \\
\text { Portugal, } \\
\text { Romania, } \\
\text { Spain, Sweden, } \\
\text { Switzerland, } \\
\text { United Kingdom }\end{array}$ & & \\
\hline & & \multicolumn{2}{|c|}{ Africa } & \\
\hline $\begin{array}{l}\text { Australia, Austria, Bulgaria, } \\
\text { Croatia, Czechia, Denmark, } \\
\text { Finland, France, Germany, } \\
\text { Greece, Hungary, Ireland, } \\
\text { Italy, Japan, Luxembourg, } \\
\text { Netherlands, New Zealand, } \\
\text { Norway, Poland, Portugal, } \\
\text { Romania, Spain, Sweden, } \\
\text { Switzerland, United } \\
\text { Kingdom }\end{array}$ & $\begin{array}{l}\text { Bahrain, China, } \\
\text { India, Indonesia, } \\
\text { Iran, Israel, } \\
\text { Jordan, Kuwait, } \\
\text { Malaysia, } \\
\text { Philippines, } \\
\text { Qatar, Saudi } \\
\text { Arabia, } \\
\text { Singapore, Sri, } \\
\text { Lanka, Thailand, } \\
\text { Turkey }\end{array}$ & \multicolumn{2}{|c|}{$\begin{array}{l}\text { Angola, Benin, Botswana, } \\
\text { Burkina Faso, Cameroon, } \\
\text { Central African Republic, } \\
\text { Cote d Ivoire, Egypt, Gabon, } \\
\text { Kenya, Mauritius, Morocco, } \\
\text { Mozambique, Namibia, } \\
\text { Niger, Nigeria, Rwanda, } \\
\text { Senegal, Sierra Leone, South } \\
\text { Africa, Sudan, Togo, Tunisia, } \\
\text { Zimbabwe }\end{array}$} & $\begin{array}{l}\text { Dominican Republic, } \\
\text { Ecuador, Guatemala, } \\
\text { Honduras, Jamaica, } \\
\text { Mexico, Nicaragua, } \\
\text { Panama, Paraguay, } \\
\text { Peru, Uruguay, } \\
\text { Venezuela }\end{array}$ \\
\hline
\end{tabular}


Appendix B.

List of Variables and Data Sources

\begin{tabular}{ll}
\hline \multicolumn{1}{c}{ Variables } & \multicolumn{1}{c}{ Source } \\
\hline Per capita income (constant 2010 US\$) & World Bank \\
Total factor productivity & Penn World Table 9.1 \\
Human capital & Penn World Table 9.1 \\
Export concentration & UNCTAD \\
Foreign direct investment net inflow \% to GDP & World Bank \\
Trade openness as \% GDP & World Bank \\
Domestic credit to private sector as \% to GDP & World bank \\
General government final consumption expenditure as \% to GDP & World bank \\
Gross fixed capital formation as \% to GDP & World bank \\
\hline
\end{tabular}

